\title{
Implications of Being a Highly Rated Organization: Evidence from
}

\section{Four-Star Rated Nonprofits}

\author{
Qianhua (Q.) Ling \\ College of Business Administration, Marquette University \\ PO Box 1881, Milwaukee, WI 53201, USA
}

Tel: 1-414-288-8069Ｅ-mail: qianhua.ling@marquette.edu

Daniel Gordon Neely

Sheldon B. Lubar School of Business, University of Wisconsin-Milwaukee

Lubar Hall N320, 3202 North Maryland Avenue, Milwaukee, WI 53211, USA

Tel: 1-414-229-4164 E-mail: neely@uwm.edu

Received: March 6, 2012

Accepted: March 30, 2012

Published: May 15, 2012

doi:10.5430/afr.v1n1p3

URL: http://dx.doi.org/10.5430/afr.v1n1p3

The two authors have equal contribution to this study. We gratefully acknowledge the research assistance of Josie Liu. We thank Guidestar for providing some of the data used in this study. We also acknowledge the financial support from the Helen Bader Institute for Nonprofit Management.

\begin{abstract}
This study examines a group of nonprofits rated four stars by Charity Navigator. The purpose is to determine whether this select group of charities exhibits characteristics associated with top charitable organizations, or whether the four-star rating achieved is limited to the more narrow financial metrics employed in the methodology utilized by Charity Navigator. This study finds that organizations rated four stars by Charity Navigator show a lower level of excess cash holdings, report a lower level of compensation expenses and exhibit lower sensitivity of compensation to performance. Financially, these organizations are less vulnerable than their lower rated peers. The results from this study shed light on the continuing debate of the effectiveness of rating agencies to accurately identify top performing charitable organizations.
\end{abstract}

Keywords: Nonprofits, Rating agencies, Information intermediaries

\section{Introduction}

The current economic period in the United States has been dubbed the "Great Recession," and for good reason. From the start of the current economic downturn in December 2007, GDP has declined significantly while the unemployment rate has soared (Isidore 2009). The economic decline has placed considerable strain on nonprofit organizations delivering social services. The recession has seen a drop in funding to nonprofits while at the same time demand for basic living services such as food and shelter has risen sharply (Cardwell 2009). In fact, over half of charities have seen a decrease in donations in 2009, and 93\% are feeling the effects of the downturn (Strott 2009). The competition for donations is fierce while donors have significantly fewer resources to allocate to charitable organizations.

Increasingly, charity monitoring groups have stepped into a prominent role in the market for charitable giving. Traffic to the websites of these monitoring groups is growing, further increasing their collective clout as information intermediaries in the market for contributions (Lowell et al. 2005). Two of the largest of these groups are the Better Business Bureau Wise Giving Alliance and Charity Navigator (Lowell et al. 2005). Prior research has found that donors respond to assessment of the Better Business Bureau Wise Giving Alliance (Chen 2009; Sloan 2008) and star ratings of Charity Navigator (Gordon et al. 2009). However, criticism abounds as to the effectiveness of ratings. Critics note that charitable organizations are complex and that ratings focused on financial ratios fail to adequately measure the impact a charitable organization has made towards its chosen mission (Niehaus 2003; Lowell et al. 2005). 
The purpose of this study is to examine a group of nonprofit organizations rated four stars by Charity Navigator, to determine whether this select group of charities exhibits characteristics associated with top charitable organizations, or whether the four-star rating achieved is limited to the more narrow financial metrics employed in the methodology utilized by Charity Navigator. The findings suggest that organizations rated four stars by Charity Navigator report a lower level of excess cash holdings and executive compensation than their lower rated peers. In addition, compensation paid to executives of four-star charities is less sensitive to external performance metrics and the sensitivity is weaker when more resources are available. Finally, financially, four-star rated charities are less vulnerable than their zero- to three-star peers after controlling for size. Overall, four-star organizations exhibit some desirable characteristics beyond the financial metrics used to rate them. The results of this study shed light on the continuing debate of the effectiveness of rating agencies to accurately identify top performing charitable organizations.

The remainder of this paper is organized as follows. The next section introduces Charity Navigator and discusses studies that have examined the characteristics of rated organizations. Our research questions are discussed in the third section. The fourth section describes the sample and data, followed by our analyses in the fifth section. This paper is concluded with limitations and a few final remarks.

\section{Charity Navigator and Prior Literature}

\subsection{Charity Navigator}

Charity Navigator, named one of the fifty coolest websites by Time (2006), was visited by more than four million donors in 2008 and is the largest of the charity rating agencies (Charity Navigator 2009). Among numerous accolades the website has received a Forbes award for "Best of the Web" twice, was chosen by PC World as "One of America's Top Websites," and in 2007, was inducted into BusinessWeek's "Philanthropy Hall of Fame" for "revolutionizing the process of giving" (Charity Navigator 2009).

Charity Navigator aims to help individual donors to choose contribution recipients. Consistent with this goal, Charity Navigator evaluates only public charities. More specifically, these public charities show strong dependence on public donations. They report at least $\$ 500,000$ public support in the most recent fiscal year. They also have filed Form 990 s with the Internal Revenue Service (IRS) for at least four years and they are based in the United States. These organizations do not need to have any relation with Charity Navigator. In addition, donors can place a request of rating for organizations they are interested in.

Charity Navigator assigns points to each organization it rates in seven categories. The seven categories include program expense ratio, administrative expense ratio, fundraising expense ratio, fundraising efficiency, revenue growth, program expense growth, and working capital. Each of the seven categories is worth a maximum of ten points. Thus, a charity meeting the top requirement in each category would receive a maximum of 70 points. A charity that receives at least 60 total points receives a four-star rating from Charity Navigator. Conversely, a charity with less than 25 total points would receive zero stars. (Note 1) An organization rated four-stars has obtained the best rating Charity Navigator offers and is widely cited as an exemplary organization. Charity Navigator prominently displays four-star rated organizations by providing a link on its homepage to an exclusive list of four-star organizations. Organizations also proudly display the four-star rating on their websites. (Note 2) Further validating the significance of the Charity Navigator ratings, Gordon et al. (2009) find that a change in the star rating of an organization is associated with a concurrent change in contributions flowing into the organization. A follow up study by Grant (2010) supports the notion that donors respond to the Charity Navigator ratings. (Note 3) The significance of the four-star rating motivates the significance of studying the underlying characteristics of these organizations.

\subsection{Review of the Extant Literature}

While the academic study of rating agencies is in its infancy in the nonprofit sector, there exists a robust literature on the effectiveness of ratings in the for-profit sector. Rating agencies such as Moody's and Standard and Poor's have long provided ratings of bond and stock issues of publicly traded companies. Prior literature has found that a refinement in Moody's Rating system leads to an increase in debt value, a fall in equity value, and a decline in the volatilities implied by the price of options when Moody's announces better than expected ratings (Kliger and Sarig 2000). In addition, excess bond returns are associated with rating changes by Moody's and Standard and Poor's (Hand et al. 1992). The information content of the credit ratings increased after Regulation FD and nonpublic disclosures were limited (Jorion et al. 2005). Finally, recent conservatism exhibited by the rating agencies has affected the debt spreads and capital structure of companies (Baghai et al. 2011).

Not to be outdone, equity analysts will make buy and sell recommendations based on their review of the value of the stock relative to its market value. Prior literature has found that the release of analyst's buy (sell) recommendations is associated with an increase (decrease) in stock price even when there is no new information released about a stock 
(Womack 1996). In decomposing analysts' recommendations, stocks with strong buy recommendations tend to have more recent positive EPS momentum and surprise, recent positive relative price momentum, and recent positive EPS forecast revisions (Stickel 2007). These stocks also have stronger balance sheets and have higher long-term EPS growth forecasts (Stickel 2007). Similar to the literature on rating agencies and analyst in the for-profit sector, this study builds off of Gordon et al. (2009) to determine the characteristics of four-star organizations and information content signaled to the market for charitable contributions. The next section discusses our research questions.

\section{Research Questions}

One marked difference between for-profit and nonprofit enterprises is that a nonprofit organization lacks a residual claimant (i.e. no shareholders). Fama and Jensen (1983, pg. 342) conclude that "The absence of residual claims avoids the donor-residual claimant agency problem and explains the dominance of nonprofits in donor-financed activities." This has been a common view shared by many concerning the level of agency cost in nonprofit organizations. However, agency problems do exist in nonprofit organizations in the form of excessive compensation and entrenchment, and these problems are exacerbated if the nonprofit organization is not properly monitored (Hansman 1996). The relatively weak outside monitoring mechanisms, coupled with the fact that the typical nonprofit Board of Directors serves primarily in a fundraising capacity result in few monitors of management activities. Fisman and Hubbard (2005) note that organizations will hold precautionary savings, which is referred to as cash holdings in the context of this study, to guard against adverse revenue or expenditure shocks. However, they note that the presence of a fund balance to smooth expenditures "may facilitate managerial 'stealing,' analogous to the free cash holdings described by Jensen and Meckling (1976) in for profits" (Fisman and Hubbard 2005, pg. 2232).

Truly exemplary nonprofit organizations are expected to be well run and avoid the agency problems of excess cash holdings and compensation that plagues troubled nonprofits. Core et al. (2006) examine various interpretations for excess endowment holdings in charitable nonprofits. (Note 4) The authors find that nonprofit organizations with persistent excess endowments do not exhibit higher growth in program expenses or investments. They also find that the program expense ratio (program expenses divided by total expenses) is lower for organizations with excess endowments and there is a positive association between excess endowments and compensation. They conclude that excess endowments are associated with greater agency problems. Given the fact exemplary nonprofit organizations are expected to have less severe agency problems, our first research question tests whether four-star organizations have a lower level of excess cash holdings compared to their lower rated peers. Our first research question is stated as follows:

RQ1: Do organizations rated four stars by Charity Navigator have a lower level of excess cash holdings compared to their lower rated peers?

A positive relation between executive pay and performance has long been established (Jensen and Murphy 1990). The positive relation between pay and performance has also been established in nonprofit organizations (Baber et al. 2002). Recently, research has found results consistent with high performing companies having a greater level of pay for performance sensitivity in compensation (Baek and Pagan 2006). However, it is not clear whether highly rated nonprofit organizations should exhibit a greater pay for performance sensitivity. Critics of external performance measures, such as the ratio of program expenses to total expenses, argue that these measures do not capture how effectively a nonprofit achieves its mission (Pallotta 2008) (Note 5). If executives of highly rated nonprofit organizations are more effective at achieving the organization missions and this effectiveness is mainly captured in unobservable performance metrics, than we would expect highly rated nonprofit executives to exhibit a lower pay for performance sensitivity. Research question 2a tests whether four-star organizations have a differential pay for performance sensitivity compared with their lower rated peers.

\section{RQ2a: Do four-star organizations exhibit a differential pay for performance sensitivity than their lower rated peers?}

Donors to charitable organizations are diffuse and there have been calls from advocates for increasing donor scrutiny of the practices of nonprofits to ensure that compensation is just and reasonable (Frumkin 2001). Regulators and Congress have responded to the concerns over compensation practices of nonprofits by probing nonprofits about their compensation practices and procedures (IRS 2004). In addition, the Panel on the Nonprofit Sector issued a report sent to Congress and the IRS, recommending more than 120 actions be taken by the IRS, Congress, and charitable organizations (Clolery 2005). Among the actions to be taken the Panel recommended that Congress strengthen the penalties levied on board members who approve and executives who receive excessive compensation, that the IRS revise the Form 990 to make the total compensation of executives clearer to the public and regulators, and that charitable organization boards approve executive compensation each year. Research question $2 \mathrm{~b}$ tests whether four-star organizations have a lower level of compensation compared with their lower rated peers. 


\section{RQ2b: Do four-star organizations have a lower level of compensation compared to their lower rated peers?}

A major role rating agencies play in the market for charitable contributions is to decipher which organizations are financially strong and which organizations are ill prepared to weather the economic down cycles. It was reported that 93 percent of nonprofits experienced the effects of the recent downturn, and 80 percent had experienced cuts in their funding (Strott 2009). Organizations in financial distress are more likely to cut back on services to the community thereby less effectively fulfilling the organization's mission. A financially healthy organization reassures donors that contributions will go towards fulfilling the mission and not to prop up a financially distressed organization. Research question three tests whether four-star organizations are more financially viable then their lower rated peers.

\section{RQ3: Do four-star organizations exhibit less financial vulnerability than their lower rated peers?}

\section{Sample Selection and Data}

\subsection{Sample Selection}

Our sample selection procedures are reported in Table 1 . We collected rating information from the Charity Navigator website in September 2008. The ratings are for 1,041 unique charities in human services. (Note 6) We retrieve the financial information of these charities from their Form 990s. The 2004-2007 information is obtained from the GuideStar database and supplemented with hand collected data. The 1999-2003 information is digitized financial data from the National Center for Charitable Statistics (NCCS). We could not obtain financial information for 113 charities. We further reduce the sample for missing or outlier values of compensation. Our final sample includes 815 charities. Because the investigation of each research question requires different financial data, the number of observations may vary from model to model. For example, the excess cash holding model requires five consecutive years of financial data while the compensation model does not. In cases such as missing one year of data, it affects the sample size of the excess cash holding model more than the compensation model.

[Insert Table 1 here]

\subsection{Data}

Table 2 presents the descriptive statistics for the 815 charities over their rating years. The mean (median) of total assets is $\$ 19.503$ (\$6.001) million. The mean (median) of total revenue is $\$ 19.829$ (\$5.371) million. The fact that the means are greater than the medians suggests the importance of controlling for size in later analyses. We specify compensation as the total compensation to current and former officers, directors, key employees, and disqualified persons (column A of lines 25a, 25b, and 25c). The mean (median) compensation is $\$ 239$ thousand ( $\$ 143$ thousand). The change measures have fewer observations because of additional data requirements. The mean (median) change in revenue is $\$ 2.471$ (\$0.274) million. The mean (median) percent change in total compensation is 17.1 percent (6 percent). Approximately 11 percent of the sample changes their rating to a four-star. On average, liabilities are about 18.6 percent of total assets. Administrative expenses are approximately 8.7 percent of total revenue.

[Insert Table 2 here]

The sample includes 49 zero-star, 226 one-star, 556 two-star, 828 three-star, and 673 four-star ratings. In Table 3, we report the descriptive statistics by rating. The statistics show that in the rating year, differences in total assets by rating are not as much as those in total revenue or total expenses. The four-star group has greater changes in total revenue than other groups do. The median total compensation is comparable from the one-star group to the four-star group, and the majority of their compensation has increased from the previous year. Program ratios, program expenses as a percentage of total revenue, are generally greater in the three- and four-star groups, but there are also high ratios in the one- and two-star groups. Compared to the previous year, most program ratios are lower. This is the case across all rating groups. Liabilities in the four-star group are a smaller fraction of total assets than those in other groups. The difference between total revenue and total expenses scaled by total revenue, defined as margin in this study, is higher in the four-star group than in other groups. Administrative expenses are a smaller percentage of total revenue in the four-star group than in other groups. Details are presented in Table 3.

[Insert Table 3 here]

\section{Findings}

In this section, we empirically examine the characteristics of four-star charities. We compare excess cash holdings of four-star charities with those of their lower rated peers in the year following the rating. We examine whether the pay-performance association is different for four-star charities than for all other charities. We also compare four-star charities and other charities in financial vulnerability in the future. 


\subsection{RQ1: Excess Cash Holdings}

Following Core et al. (2006), we measure excess cash holdings as the residual of the cash holding expectation model:

Cash Holdings $_{i t} /$ Expenses $_{i t}=\beta_{0}+\beta_{1}$ CVRev $_{i t}+\beta_{2}$ Ln Revenue $_{i t}+\beta_{3}$ Access to Debt $_{i t}+\beta_{4}$ Access to Debt $^{*}$ CVRev $_{i t}+\beta_{\mathrm{j}}$ State $+\beta_{\mathrm{m}}$ Year $+\varepsilon_{i t}$

where Cash Holdings is liquid assets that is the sum of cash (line 45, column b), savings (line 46, column b), investments on publicly-traded securities (line 54a, column b), and investments on other securities (line 54b, column b); Expenses is total expenses (line 17); CVRev is the coefficient of variation of total revenue (line 12), measured as the ratio of the standard deviation of total revenue to the mean of total revenue over the last five years up to the year of rating; Ln Revenue is the natural logarithm of total revenue (line 12); Access to Debt is an indicator variable, equal 1 if the charity has tax-exempt bond liabilities (line 64a, column b) or mortgages and other notes payable (line 64b, column b) in the last five years up to the year of rating; Access to Debt*CVRev is the interaction term of Access to Debt and CVRev; State is the indicator variable of the state where the organization is incorporated; and Year is the indicator variable of the rating year. (Notes $7 \& 8$ )

This expectation model captures the factors that determine the level of precautionary funds. It is expected that charities with fluctuating revenue, captured by CVRev, require a large amount of cash holdings to deal with uncertainty. In contrast, large charities, measured by Ln Revenue, and charities with access to debt, measured by Access to Debt, have a lower demand for readily available funds. Having access to debt also mediates the pressure brought by the fluctuation in revenue. Indicator variables, State, control for differences across states in legal environment, reporting requirements, income level, demand level for charitable service, and growth opportunity for charities. Indicator variable, Year, controls for year-specific variations in economic, legal, and social events. Continuous variables in model (1) are winsorized by year at the 1 and 99 percent levels.

Table 4 reports the results of the comparison of excess cash holdings. In Panel A of Table 4, the two-sample t-test shows that in the year following the rating, the excess cash holdings of four-star charities are significantly lower than those of other charities $(\mathrm{t}=-3.86, \mathrm{p}=0.00)$. As descriptive analyses in Table 2 indicate that sample charities are skewed in size, we further test whether the difference in excess cash holdings is essentially a size effect. We match the four-star charities with the zero- to three-star charities by various measures of size and then compare their excess cash holdings. Charities from the two rating groups are first matched on total assets. The $z$-test $(z=-4.79, p=0.00)$ shows that charities with a four-star rating have significantly less excess cash holdings than their lower rated peers in the year following the rating. Charities are next matched on total revenue. Four-star charities show significantly lower excess cash holdings than zeroto three-star charities in the year after the rating $(z=-4.16, p=0.00)$. When charities are matched on direct support, the phenomenon of lower excess cash holdings for four-star charities still exists in the year after the rating $(\mathrm{z}=-3.06, \mathrm{p}=$ $0.00)$. Matching the charities on total contribution, four-star charities exhibit lower excess cash holdings than their lower rated peers in the year after rating $(\mathrm{z}=-2.62, \mathrm{p}=0.01)$. When charities are matched on unrestricted assets as reported, the z-test shows that four-star charities have a significantly lower level of excess cash holdings than their lower rated peers $(\mathrm{z}=-5.19, \mathrm{p}=0.00)$. In sum, charities rated four stars have significantly lower excess cash holdings compared to their lower rated peers, and this phenomenon is not driven by size. (Note 9)

[Insert Table 4 here]

\subsection{RQ2a and RQ2b: Pay-Performance Association and Executive Compensation}

To examine the association between pay and performance and whether four-star charities behave differently than other charities, we test the following level model:

Ln Compensation $_{i t}=\beta_{0}+\beta_{1}$ Ln Revenue $_{i t}+\beta_{2}$ Ln Program Ratio $_{i t}+\beta_{3} 4-$ Star $_{i t}$

$+\beta_{4}$ Ln Revenue $_{i t} * 4-$ Star $_{i t}+\beta_{5}$ Ln Program Ratio ${ }_{i t} * 4-$ Star $_{i t}$

$+\beta_{\mathrm{j}}$ State $+\beta_{\mathrm{m}}$ Year $+\varepsilon_{i t}$

where Ln Compensation is the natural logarithm of total compensation (column A of lines 25a, 25b, and 25c); Ln Program Ratio is the natural logarithm of program expenses (line 13) as a ratio of total expenses (line17); 4-Star, an indicator variable, equals 1 if the rating is a four-star, and 0 otherwise; State and Year are indicator variables as defined in model (1).

This model is in the spirit of the Baber et al. (2002) model that compensation is a function of both resources available and the relative spending on charitable services. The effects of individual age, experience, and tenure with the charity are assumed to be random, as the dependent variable is total compensation to a wide range of people, including current and former officers, directors, key employees, and disqualified persons. The benchmark model in column (I) of Table 5 
does not include 4-Star and its interaction terms. It shows that total compensation and total revenue are positively associated, while total compensation and the program expense as a percentage of total expenses are not. It appears that program ratio is not as emphasized as total revenue in compensation. In column (II), we add the 4-Star variable to the model. The coefficient on this variable is significantly negative, suggesting that after controlling for revenue and program ratio, four-star charities are associated with lower compensation. Adding the interaction between 4-Star and Ln Revenue to the model in column (III), only the coefficient on Ln Revenue is significantly different than zero. In column (IV), the interaction between 4-Star and Ln Program Ratio is significantly negative, suggesting that the sensitivity of pay to relative performance is weaker for four-star charities than for other charities. The complete model in column (V) shows that the coefficient on the three-way interaction term is significantly negative, suggesting that the pay to relative performance is weaker when more resources is available for four-star charities than for zero- to three-star charities.

In summary, after controlling for resources available and relative performance in charitable service, four-star charities exhibit lower total compensation than other charities do. The compensation sensitivity to relative performance is weaker for four-star charities than for all other charities. And the sensitivity is even weaker when more resources are available.

[Insert Table 5 here]

\subsection{RQ3: Financial Vulnerability}

In this section, we compare the financial vulnerability of four-star charities with that of their lower-rated peers. We use two models to estimate the financial vulnerability index (FVI). Our first measure, FVI_l, follows Greenlee and Trussel (2000):

$$
\text { FVI_1 }=1 /\left(1+e^{-\mathrm{z}}\right)
$$

where, $Z=-3.0610+0.1153 *$ Equity $+1.2528 *$ Concentration $-2.2639 *$ Admin $-3.4289 *$ Margin; Equity is total equity (line $59 \mathrm{~b}$ - line 66b) divided by total revenue (line12); Concentration is the revenue concentration ratio, which is the total of the squares of each revenue source as a percentage of total revenue; Admin is the administrative expense (line 14) scaled by total revenue (line 12); and Margin is the difference between total revenue (line 12) and total expense (line 17) and then scaled by total revenue. Greenlee and Trussel (2000) suggest that a greater than 0.10 value is a strong indicator of financial vulnerability, a less than 0.07 value is a strong indicator of no financial vulnerability, and a value in between 0.07 and 0.10 is not a clear indicator of either situation.

Our second measure, FVI_2, follows Trussel et al. (2002). Here, the estimation of $Z$ is primarily modified by taking size into consideration: $Z=0.7754+0.9272 *$ Debt $+0.1496 *$ Concentration $+0.1206 *$ Admin $-2.8419 *$ Margin $-0.1665 *$ Size ; where Debt is total liabilities (line 66b) scaled by total assets (line 59b); Size is the natural logarithm of total assets (line $59 \mathrm{~b}$ ); and other variables are defined as above. Because of the change in the model, Trussel et al. (2002) adjust the cutoff point for the assessment of financial vulnerability. If the value is greater than 0.20 , then it indicates that the charity will be financially vulnerable. If the value is less than 0.10 , then it indicates that the charity will not be financially vulnerable. No clear indication is made by a value in the range of 0.10 and 0.20 .

We compute all the financial measures used in the calculation of FVI_l and FVI_2. We check the correlations between these measures and the seven measures used by Charity Navigator to rate nonprofit organizations. Note that Admin in the calculation of FVI is scaled by total revenue and the Administration Expense by Charity Navigator is scaled by total functional expenses. As reported in Table 6 Panel A, these two measures are significantly correlated. The correlation between Equity and Working Capital Ratio is also relatively high. This is because working capital is calculated in a similar way as equity. Except for the Spearman correlation between Admin and Program Expenses, the absolute values of other correlations between the two groups are not greater than 0.50 , suggesting that it is unlikely that there is a mechanical relation between the Charity Navigator rating and the financial vulnerability index. In addition, the correlations between 4-Star and the variables used to calculate the financial vulnerability index are low - the absolute values of these correlations are less than 0.22 . To further reduce the concern for mechanical relation, we compare the financial vulnerability measures in the year after the rating.

In Table 6 Panel B, we compare financial vulnerability across rating groups. Four-star charities have comparable $F V I \_l$ values as other charities do $(\mathrm{t}=-0.81, \mathrm{p}=0.42)$. However, when the size effect is considered in the calculation of the index such as in FVI_2, four-star charities exhibit significantly lower $F V I \_2$ values than other charities do $(\mathrm{t}=-3.69$, $\mathrm{p}=0.00$ ). We further define $L F V_{-} 1$ as 1 if $F V I_{-} 1$ indicates that the charity will not be in financial trouble, and 0 otherwise. $L F V \_2$ is defined in a similar way based on the value of FVI_2. Comparing the means of $L F V \_1$, the t-test indicates that four-star charities do not have advantages in financial health $(t=0.27, p=0.79)$. However, the test of the difference in the means of $\mathrm{LFV}_{-} 2$ suggests that more four-star charities are financially healthy than charities in lower 
rated groups $(\mathrm{t}=1.85, \mathrm{p}=0.07)$. Table 6 provides evidence that after controlling for size, four-star charities exhibit characteristics consistent with low probability of financial vulnerability in the future.

[Insert Table 6 here]

\subsection{Comparison with Three-Star Charities}

Charity Navigator star ratings are derived from numeric scores. The difference in the numeric scores between a four-star (60-70) and a three-star (50-60) rating is less than 20 points. We examine whether the characteristics four-star charities exhibit above still hold when they are only compared with the closely rated three-star charities. The results show that four-star charities have significantly less excess cash holdings than three-star charities do in the year after rating. The sensitivity of compensation to performance is similar for four-star charities and three-star charities. Four-star charities are comparable to three-star charities in the probability of being financially vulnerable and the percentage of financially stable charities is not significantly different for these two rating groups. Overall, four-star charities exhibit characteristics associated with lower agency costs relative to three-star organizations.

\section{Limitations and Concluding Remarks}

The importance of rating agencies in the market for charitable contributions has been well documented in the literature (Gordon et al. 2009; Chen 2009; Sloan 2008). Charity Navigator, one of the largest rating agencies, has grown in influence in recent years. However, a lingering question has been how informative the ratings by the rating agencies are. Specifically, this study addresses whether the Charity Navigator four-star rating truly represents exemplary nonprofit organizations. When compared to organizations rated toward the bottom of Charity Navigator's rating scale ( $0 \sim 3$ stars), we find that four-star organizations have a lower level of excess cash holdings. This finding validates Charity Navigator four-star organizations as having a lower level of agency problems, a finding we would expect among top rated nonprofit organizations. Top rated organizations are expected to be financially secure to effectively carry out their mission. As expected, we find that four-star organizations are less financially vulnerable than their lower rated peers. Finally, we find that four-star rated organizations have lower levels of executive compensation and a lower level of pay for performance sensitivity compared to their lower rated peers. The compensation finding is interesting and should provide further support for four-star rated organizations prudently managing resources. In sum, four-star organizations present some characteristics consistent with what the public desire for top nonprofit organizations.

There are a couple of limitations to this current study. First, Charity Navigator only rates a sample of larger nonprofits. Findings from this study do not generalize to the majority of nonprofits that are not rated by Charity Navigator. Second, our study highlights characteristics associated with a four-star rating. We cannot draw a causal link between these characteristics and achieving a high rating. Additionally, our study focuses on one sector of nonprofit organizations, human services, and thus, our findings may not be generalized to other nonprofit sectors.

Notwithstanding the limitations of the study, the results of this study should be of interest to nonprofit stakeholders and others with an interest in the market for charitable contributions. This study provides empirical evidence validating the growing role information intermediaries are playing in the market for charitable contributions and sheds light on the debate of the credibility of the ratings of nonprofit organizations. Fruitful avenues of future research would be to further investigate the implications of consistency across ratings agencies, as well as developing additional metrics by which nonprofit organizations, and by extension, rating agencies may be judged.

\section{References}

Baber W.R., Daniel P.L., \& Roberts A.A. (2002). Compensation to managers of charitable organizations: An empirical study of the role of accounting measures of program activities. The accounting review, 77(3), 679-693. http://dx.doi.org/10.2308/accr.2002.77.3.679

Baghai, R., Servaes, H. and Tamayo, A. M. (2011). Have rating agencies become more conservative? Implications for capital structure and debt pricing. CEPR Discussion Paper No. DP8446. [Online] Available: http://ssrn.com/abstract=1871557.

Baek, H.Y., \& Pagan J.A. (2006). Pay-performance sensitivity and high performing firms. International research journal of finance and economics, 5, 78-94.

Bialik, C. (2008). Currents: The numbers guy: Charity rankings giveth less than meets the eye --- The ratings of nonprofits are often uncharitable, sometimes failing to credit crucial factors such as success. The Wall Street journal, December 19, A.13.

Carroll, T., Hughes P., \& Luksetich W. (2005). Managers of nonprofit organizations are rewarded for performance. Nonprofit management \& leadership, 16 (1), 19-41. http://dx.doi.org/10.1002/nml.88 
Cardwell, D. (2009). With donations and grants down, social service agencies feel the pinch. The New York Times, August 21. [Online] Available: http://www.nytimes.com/2009/08/22/nyregion/22nonprofit.html

Charity Navigator. (2009). Overview in the "About Us" section. [Online] Available: http://www.charitynavigator.org/index.cfm?bay=content.view\&cpid=628

Chen, G. (2009). Does meeting standards affect charitable giving? An empirical study of New York metropolitan area charities. Nonprofit management \& leadership, 19 (3), 349-365. http://dx.doi.org/10.1002/nml.223

Clolery, P. (2005). Panel report goes to Congress and IRS. The nonprofit times, August 1.

Core, J.E., Guay W.R., \& Verdi R.S. (2006). Agency problems of excess endowment holdings in not-for-profit firms. Journal of accounting and economics, 41, 307-333. http://dx.doi.org/10.1016/j.jacceco.2006.02.001

Fama, E., \& Jensen M. (1983). Agency problems and residual claims. Journal of law and economics, 26, 301-325. http://dx.doi.org/10.1086/467037

Fisman R., \& Hubbard R.G. (2005). Precautionary savings and the governance of nonprofit organizations. Journal of public economics, 89, 2231-2243. http://dx.doi.org/10.1016/j.jpubeco.2004.10.005

Frumkin P. (2001). Are nonprofit CEOs overpaid? The public interest, Winter, 83-94.

Gordon, T.P., Knock C.L. \& Neely D.G. (2009). The role of rating agencies in the market for charitable contributions: An empirical test. Journal of accounting and public policy, 28 (6), 469-484. http://dx.doi.org/10.1016/j.jaccpubpol.2009.08.001

Grant, L.E., (2010) The response to third-party ratings: Evidence of the effects on charitable contributions. Unpublished Manuscript, University of California Santa Barbara.

Greenlee J.S., \& Trussel J.M. (2000). Predicting the financial vulnerability of charitable organizations. Nonprofit management \& leadership, 11 (2), 199 - 210. http://dx.doi.org/10.1002/nml.11205

Hallock, K.F. (2002). Managerial Pay and Governance in American Nonprofits. Industrial relations, 41 (3), 377-406. http://dx.doi.org/10.1111/1468-232X.00252

Hand, J.R.M., Holthausen R.W., \& Leftwich R.W. (1992). The effect of bond rating agency announcements on bond and stock prices. The journal of finance, 47 (2), 733-752. http://dx.doi.org/10.2307/2329121

Hansmann, H. (1996). The ownership of enterprise. Cambridge, MA: Belknap Press.

IRS. (2004). IRS Initiative will scrutinize EO compensation practices. [Online] Available: http://www.irs.gov/newsroom/article/0,id=128328,00.html

Isidore, C. (2009). The Great Recession. CNNMoney.Com. March 25 ${ }^{\text {th }}$. [Online] Available: http://money.cnn.com/2009/03/25/news/economy/depression_comparisons/

Jensen M.C., \& Murphy K.J. (1990). Performance pay and top-management incentives. Journal of political economy, 98 (2), 225 - 264. http://dx.doi.org/10.1086/261677

Jorion, P., Liu Z., \& Shi C. (2005). Informational effects of Regulation FD: Evidence from rating agencies. Journal of financial economics, 76 (2), 309-330. http://dx.doi.org/10.1016/j.jfineco.2004.05.001

Kliger, D., \& Sarig, O. (2000). The Information value of bond ratings. The journal of finance, 55 (6), 2879-2902. http://dx.doi.org/10.1111/0022-1082.00311

Lowell, S., Trelstad B., \& Meehan B. (2005). The ratings game: Evaluating the three groups that rate the charities. Stanford social innovation review, Summer, 38-45.

Niehaus, P. (2003). Rating the charity raters: Measuring the charity raters is more than a matter of money. Capital research center organizational trends, October, 1-6.

Oster, S.M. (1998). Executive compensation in the nonprofit sector. Nonprofit management \& leadership, 8 (3), 207-221. http://dx.doi.org/10.1002/nml.8301

Pallotta, D. (2008). Uncharitable: How restraints on nonprofits undermine their potential. Bedford, Massachusetts: Tufts University Press.

Sloan, M.F. (2008). The effects of nonprofit accountability ratings on donor behavior. Nonprofit and voluntary sector quarterly, 38 (2), 220-236. http://dx.doi.org/10.1177/0899764008316470 
Szper, R. \& Prakash.A. (2011). Charity Watchdogs and the Limits of Information-Based Regulation. Voluntas: International Journal of Voluntary and Nonprofit Organizations. 22: 112 - 141. http://dx.doi.org/10.1007/s11266-010-9156-2

Stickel, S.E. (2007). Analyst Incentives and the financial characteristics of Wall Street darlings and dogs. The journal of investing, 16 (3), 23-32. http://dx.doi.org/10.3905/joi.2007.694759

Strott, E. (2009). Charities face grim holidays. MSNMoney, December 10 ${ }^{\text {th }}$, [Online] Available: http://articles.moneycentral.msn.com/SavingandDebt/SaveMoney/charities-face-grim-holidays.aspx

TIME Magazine. (2006). 50 Coolest Websites for 2006, August. [Online] Available: http://www.time.com/time/2006/50coolest/index.html.

Trussel J., Greenlee J.S., \& Brady T. (2002). Predicting financial vulnerability in charities. The CPA journal, June, 66-69.

Womack, K.L. (1996). Do brokerage analyst's recommendations have investment value? The journal of finance, 51 (1), 137-167. http://dx.doi.org/10.2307/2329305

Note 1. For a current review of the Charity Navigator methodology, please visit its website at www.charitynavigator.org.

Note 2. A search for four-star organizations revealed multiple organizations that prominently displayed their four stars Charity Navigator rating. In fact, Charity Navigator informs organizations of their four-star ratings and offers a specialized logo the charity can use to prominently display their four-star rating. This service is only offered to four-star organizations per the Charity Navigator website. Please refer to the following link for details: http://www.charitynavigator.org/index.cfm?bay=content.view\&cpid=483\#74.

Note 3. An exception to studies finding that ratings matter is Szper and Prakash (2011). They find no association between a change in star rating and a change in contributions.

Note 4. Core et al. (2006) use the term "excess endowment." We use the term "excess cash holdings" to avoid the confusion with the general meaning of "endowment" as a permanently restricted fund balance.

Note 5. Consider the case of a food bank. Two organizations (A and B) can spend $80 \%$ of their total dollars on program related expenses. However, organization A is able to serve twice as many needy families as organization B by reducing program related staff, and centralizing distribution of food services.

Note 6. We decided to focus on one major classification, human services, to ensure variation in ratings and to eliminate potential differences across organization classifications.

Note 7. Due to data limitation, we define the variable Access to Debt using five years instead of ten years of data as in the Core et al. (2006) study. We do not include indicator variables for industry as Core et al. (2006) do because charities in our sample are all from the human services category.

Note 8. The line numbers correspond to the line numbers on the Form 990.

Note 9. Because management may have limited access to restricted assets for precautionary purpose, Core et al. (2006) scaled the unrestricted assets measure by total expenses and used it as the dependent variable in model (1). They propose to use the residual from the model as an alternative measure of excess cash holding. Our inferences are not affected by adopting this alternative measure of excess cash holding. 
Table 1. Sample selection

Human services charities rated by Charity Navigator

Charities

Less: charities with no financial information

1,041

Charity with financial data

Less: charities without consecutive years of ratings

Charities with two or three consecutive years of ratings

Less: charities with missing compensation data

Charities with financial information to estimate percent change in compensation

Less: charities only with influential observations in estimating the compensation change model

Table 2. Descriptive statistics

\begin{tabular}{|c|c|c|c|c|c|c|}
\hline Variable & $\mathrm{N}$ & Mean & Std Dev & Q1 & Median & Q3 \\
\hline Total Assets (\$) & 2332 & 19,503 & 41,229 & 2,473 & 6,001 & 15,970 \\
\hline Total Revenue (\$) & 2332 & 19,829 & 162,733 & 2,467 & 5,371 & 12,639 \\
\hline Total Compensation (\$) & 2332 & 239 & 259 & 83 & 143 & 297 \\
\hline Total Expense (\$) & 2332 & 18,544 & 152,674 & 2,274 & 5,025 & 11,484 \\
\hline Program Expense (\$) & 2332 & 16,478 & 142,127 & 1,687 & 4,016 & 9,843 \\
\hline Program Ratio & 2332 & 0.765 & 0.214 & 0.663 & 0.783 & 0.893 \\
\hline$\Delta$ Revenue (\$) & 2313 & 2,471 & 45,321 & (197) & 274 & 1,229 \\
\hline$\% \Delta$ Compensation & 2246 & 0.171 & 0.795 & 0.00 & 0.06 & 0.18 \\
\hline$\Delta$ Program Ratio & 2313 & -0.012 & 0.217 & -0.075 & -0.005 & 0.060 \\
\hline Change to 4 & 1494 & 0.110 & 0.313 & 0.000 & 0.000 & 0.000 \\
\hline Excess Cash holding & 2167 & -0.038 & 1.341 & -0.586 & -0.256 & 0.114 \\
\hline Debt & 2332 & 0.186 & 0.397 & 0.032 & 0.092 & 0.225 \\
\hline Equity & 2332 & 1.469 & 1.804 & 0.426 & 0.980 & 1.784 \\
\hline Concentration & 2332 & 0.662 & 2.940 & 0.407 & 0.559 & 0.795 \\
\hline Margin & 2332 & 0.052 & 0.229 & -0.016 & 0.038 & 0.123 \\
\hline Admin & 2332 & 0.087 & 0.092 & 0.042 & 0.078 & 0.114 \\
\hline
\end{tabular}

Dollar amounts (\$) are in thousands (000).

This table presents the descriptive statistics for the sample. Total Assets (\$) is total assets at the end of the year (line 59, column b). Total Revenue (\$) is the overall income of the year (line 12). Total Compensation (\$) is the total compensation to current and former officers, directors, key employees, and disqualified persons (column A of lines 25a, 25b, and 25c). Total Expenses (\$) is the total of program expenses, management expenses, fundraising expenses, and payments to affiliates (line 17). Program Expense (\$) is the expense on charity programs (line 13). Program Ratio is the ratio of program expense to total revenue. $\Delta$ Revenue (\$) is the difference between total revenue in year $\mathrm{t}$ and in year $\mathrm{t}-1 . \% \Delta$ Compensation is the difference of total compensation between year $\mathrm{t}$ and year $\mathrm{t}-1$ scaled by the year t-1 total contribution. $\Delta$ Program Ratio is the difference between program ratio in year $\mathrm{t}$ and year $\mathrm{t}-1$. Change to 4 is an indicator variable, equal 1 if the charity's rating changes from a non-four star rating in yea t-1 to a four-star in year t. Excess cash holdings is the excess cash holdings, measured as the residual from model (1) below.

Cash holdings $/$ Expense $_{\mathrm{it}}=\beta_{0}+\beta_{1}$ CVRev $_{i t}+\beta_{2}$ Ln Revenue $_{i t}+\beta_{3}$ Access to Debt $_{i t}+\beta_{4}$ Access to Debt $^{*}$ CVRev $_{i t}+\beta_{\mathrm{j}}$ State

$$
+\beta_{\mathrm{m}} \text { Year }+\varepsilon_{\mathrm{it}}
$$

where $C V R e v$ is the coefficient of variation of total revenue (line 12), measured as the ratio of the standard deviation of total revenue to the mean of total revenue over the last five years up to the year of rating; Ln Revenue is the natural logarithm of total revenue (line 12); Access to Debt is an indicator variable, equals 1 if the charity has tax-exempt bond liabilities (line 64a, column b) or mortgages and other notes payable (line 64b, column b) in the last five years up to the year of rating; Access to Debt*CVRev is the interaction term of Access to Debt and CVRev; State is the indicator variables for states; and Year is the indicator variables for year.

Debt is total liabilities (line 66b) scaled by total assets (line 59b). Equity is total equity (line 59b - line 66b) divided by total revenue (line 12). Concentration is the revenue concentration ratio, which is the total of the squares of each revenue source such as contributions to donor advised funds (line 1a), direct public support (line 1b), indirect public support (line 1c) and so on as a percentage of the total revenue (line 12). Margin is the difference between total revenue (line 12) and total expense (line 17) and then scaled by total revenue. Admin is the administrative expense (line 14) scaled by total revenue (line 12). 
Table 3. Descriptive statistics by rating

\begin{tabular}{|c|c|c|c|c|c|c|}
\hline $\begin{array}{c}\text { Rating }=0 \\
\text { Variable }\end{array}$ & $\mathrm{N}$ & & & & & \\
\hline $\begin{array}{l}\text { Variable } \\
\text { Total Assets (\$) }\end{array}$ & $\frac{\mathrm{N}}{10}$ & Mean & Std Dev & $\frac{Q 1}{72}$ & Median & Q3 \\
\hline Total Assets (\$) & 49 & 2,092 & 9,047 & 73 & 354 & 943 \\
\hline Total Revenue (\$) & 49 & 3,275 & 4,797 & 919 & 2,063 & 3,972 \\
\hline Total Compensation (\$) & 49 & 105 & 94 & 59 & 88 & 121 \\
\hline Total Expense (\$) & 49 & 3,450 & 5,588 & 889 & 2,079 & 4,073 \\
\hline Program Expense (\$) & 49 & 1,141 & 3,395 & 109 & 258 & 618 \\
\hline Program Ratio & 49 & 0.243 & 0.218 & 0.081 & 0.156 & 0.321 \\
\hline$\Delta$ Revenue (\$) & 49 & $(455)$ & 984 & $(858)$ & (181) & 79 \\
\hline$\% \Delta$ Compensation & 47 & -0.025 & 0.407 & -0.301 & 0.000 & 0.193 \\
\hline$\Delta$ Program Ratio & 49 & -0.042 & 0.108 & -0.071 & -0.009 & 0.014 \\
\hline Change to 4 & 28 & 0.000 & 0.000 & 0.000 & 0.000 & 0.000 \\
\hline Excess Cash holding & 42 & -0.634 & 0.702 & -1.004 & -0.527 & -0.258 \\
\hline Debt & 49 & 0.773 & 1.520 & 0.018 & 0.176 & 0.716 \\
\hline Equity & 49 & 0.273 & 0.613 & 0.020 & 0.058 & 0.398 \\
\hline Concentration & 49 & 0.897 & 0.167 & 0.840 & 0.992 & 1.000 \\
\hline Margin & 49 & -0.024 & 0.087 & -0.052 & -0.003 & 0.014 \\
\hline Admin & 49 & 0.099 & 0.085 & 0.054 & 0.075 & 0.104 \\
\hline Rating = 1 & & & & & & \\
\hline Variable & $\mathrm{N}$ & Mean & Std Dev & Q1 & Median & Q3 \\
\hline Total Assets (\$) & 226 & 9,733 & 20,432 & 1,503 & 3,225 & 7,356 \\
\hline Total Revenue (\$) & 226 & 6,426 & 14,714 & 1,591 & 3,160 & 5,650 \\
\hline Total Compensation (\$) & 226 & 202 & 198 & 87 & 141 & 234 \\
\hline Total Expense (\$) & 226 & 6,689 & 15,321 & 1,679 & 3,277 & 5,876 \\
\hline Program Expense (\$) & 226 & 4,901 & 11,692 & 1,181 & 2,150 & 4,152 \\
\hline Program Ratio & 226 & 0.718 & 0.203 & 0.617 & 0.716 & 0.806 \\
\hline ARevenue (\$) & 224 & (926) & 8,069 & $(442)$ & $(58)$ & 217 \\
\hline$\% \Delta$ Compensation & 221 & 0.132 & 0.507 & -0.057 & 0.028 & 0.176 \\
\hline$\Delta$ Program Ratio & 224 & 0.000 & 0.174 & -0.070 & -0.017 & 0.066 \\
\hline Change to 4 & 146 & 0.000 & 0.000 & 0.000 & 0.000 & 0.000 \\
\hline Excess Cash holding & 208 & -0.150 & 1.102 & -0.519 & -0.256 & 0.015 \\
\hline Debt & 226 & 0.213 & 0.301 & 0.045 & 0.136 & 0.254 \\
\hline Equity & 226 & 1.344 & 2.075 & 0.406 & 0.848 & 1.378 \\
\hline Concentration & 226 & 0.642 & 0.222 & 0.463 & 0.615 & 0.836 \\
\hline Margin & 226 & -0.036 & 0.185 & -0.089 & -0.014 & 0.039 \\
\hline Admin & 226 & 0.129 & 0.081 & 0.076 & 0.108 & 0.162 \\
\hline Rating $=2$ & & & & & & \\
\hline Variable & $\mathrm{N}$ & Mean & Std Dev & Q1 & Median & Q3 \\
\hline Total Assets (\$) & 556 & 19,232 & 41,229 & 2,159 & 5,194 & 14,997 \\
\hline Total Revenue (\$) & 556 & 10,852 & 21,000 & 2,139 & 4,701 & 11,147 \\
\hline Total Compensation (\$) & 556 & 228 & 241 & 83 & 140 & 279 \\
\hline Total Expense (\$) & 556 & 10,093 & 17,166 & 2,104 & 4,554 & 11,066 \\
\hline Program Expense (\$) & 556 & 8,409 & 14,501 & 1,620 & 3,749 & 8,833 \\
\hline Program Ratio & 556 & 0.789 & 0.232 & 0.673 & 0.791 & 0.903 \\
\hline$\Delta$ Revenue (\$) & 548 & 700 & 12,274 & $(395)$ & 99 & 640 \\
\hline$\% \Delta$ Compensation & 528 & 0.211 & 1.201 & -0.005 & 0.050 & 0.167 \\
\hline$\Delta$ Program Ratio & 548 & -0.006 & 0.242 & -0.071 & -0.007 & 0.060 \\
\hline Change to 4 & 350 & 0.000 & 0.000 & 0.000 & 0.000 & 0.000 \\
\hline Excess Cash holding & 521 & 0.099 & 1.456 & -0.511 & -0.166 & 0.146 \\
\hline Debt & 556 & 0.170 & 0.259 & 0.034 & 0.103 & 0.227 \\
\hline Equity & 556 & 1.650 & 2.142 & 0.477 & 1.035 & 1.861 \\
\hline
\end{tabular}




$\begin{array}{lcccccc}\text { Concentration } & 556 & 0.584 & 0.228 & 0.402 & 0.526 & 0.763 \\ \text { Margin } & 556 & 0.004 & 0.329 & -0.040 & 0.017 & 0.083 \\ \text { Admin } & 556 & 0.103 & 0.154 & 0.051 & 0.088 & 0.132\end{array}$

Rating $=3$

Variable

Total Assets (\$)

Total Revenue (\$)

Total Compensation (\$)

Total Expense (\$)

Program Expense (\$)

Program Ratio

$\Delta$ Revenue (\$)

$\% \Delta$ Compensation

$\Delta$ Program Ratio

Change to 4

Excess Cash holding

Debt

Equity

Concentration

Margin

Admin

Rating $=4$

Variable

Total Assets (\$)

Total Revenue (\$)

Total Compensation (\$)

Total Expense (\$)

Program Expense (\$)

Program Ratio

$\Delta$ Revenue (\$)

$\% \Delta$ Compensation

$\Delta$ Program Ratio

Change to 4

Excess Cash holding

Debt

Equity

Concentration

Margin

Admin

\begin{tabular}{c}
$\mathrm{N}$ \\
\hline 828 \\
828 \\
828 \\
828 \\
828 \\
828 \\
822 \\
802 \\
822 \\
529 \\
769 \\
828 \\
828 \\
828 \\
828 \\
828
\end{tabular}

\begin{tabular}{c} 
Mean \\
\hline 20,797 \\
13,920 \\
247
\end{tabular}

$\frac{\text { Std Dev }}{40,954}$

$\frac{\mathrm{Q} 1}{3,172}$

$\frac{\text { Median }}{7,278}$

28,968

12,919

11,227

0.774

982

0.148

$-0.005$

0.000

0.079

0.169

1.624

0.749

0.071

0.082

256

27,792

25,532

0.182

4,664

0.536

0.174

0.000

1.387

0.271

1.809

4.925

0.177

0.055

2,718

85

2,387

1,863

0.679

(143)

0.000

$-0.073$

0.000

$-0.498$

0.031

0.498

0.395

$-0.002$

0.041

6,049

153

5,445

4,667

0.783

328

0.058

$-0.002$

0.000

$-0.209$

0.091

1.124

0.529

0.050

0.078

\begin{tabular}{c}
$\mathrm{Q} 3$ \\
\hline 17,669 \\
12,890 \\
319 \\
11,656 \\
9,655 \\
0.886 \\
1,186 \\
0.178 \\
0.068 \\
0.000 \\
0.176 \\
0.223 \\
2.019 \\
0.751 \\
0.142 \\
0.111
\end{tabular}

$\frac{\mathrm{N}}{673}$

\begin{tabular}{c} 
Mean \\
\hline 22,684 \\
40,219 \\
261 \\
37,525
\end{tabular}

\begin{tabular}{c} 
Std Dev \\
\hline 47,076 \\
299,637 \\
296
\end{tabular}

\begin{tabular}{c}
$\mathrm{Q} 1$ \\
\hline 3,117 \\
3,280 \\
84 \\
2,702
\end{tabular}

$\frac{\text { Median }}{7,205}$

\begin{tabular}{c}
$\mathrm{Q} 3$ \\
\hline 18,139 \\
17,961 \\
343
\end{tabular}

673

34,607

281,170

261,853

0.789

0.184

7,096

83,039

0.195

0.747

0.258

$-0.026$

0.484

$-0.219$

1.256

0.424

1.259

1.340

0.610

0.230

0.102

0.183

0.065

0.043

2,242

0.699

105

0.008

$-0.087$

0.000

$-0.811$

0.029

0.376

0.408

0.007

0.027

143
6,280

16,458

15,416

5,467

0.814

0.907

$823 \quad 2,748$

$\begin{array}{cc}823 & 0.078 \\ 0.0202\end{array}$

$\begin{array}{ll}-0.004 & 0.055\end{array}$

$\begin{array}{ll}0.000 & 1.000\end{array}$

$\begin{array}{ll}-0.367 & 0.039\end{array}$

$\begin{array}{ll}0.076 & 0.205\end{array}$

$\begin{array}{ll}0.924 & 1.669\end{array}$

0.579

0.819

0.061

0.174

673

0.062

0.095

This table presents the descriptive statistics by Charity Navigator ratings. All variables are defined in Table 2 . 
Table 4. Comparison of excess cash holdings (rating $=4$ vs. rating $=0 \sim 3$ )

Panel A:

Rating=4
-0.212 $\frac{\text { Rating=0 3 }}{0.020} \frac{\text { Difference }}{-0.232} \frac{\mathrm{t}}{-3.86} \frac{\mathrm{p}}{0.00}$

Panel B:

\begin{tabular}{|c|c|c|c|c|c|}
\hline Matching Variable & $\mathrm{N}$ & Coefficient & Standard Error & $\mathrm{z}$ & $\mathrm{P}>|\mathrm{z}|$ \\
\hline Total Assets & 2188 & -0.362 & 0.076 & -4.79 & 0.00 \\
\hline Total Revenue & 2188 & -0.309 & 0.074 & -4.16 & 0.00 \\
\hline Direct Support & 2188 & -0.222 & 0.073 & -3.06 & 0.00 \\
\hline Total Contribution & 2188 & -0.196 & 0.075 & -2.62 & 0.01 \\
\hline Unrestricted Assets & 2188 & -0.385 & 0.074 & -5.19 & 0.00 \\
\hline
\end{tabular}

This table compares the year $t+1$ excess cash holdings of 4-star charity-years with that of $0-3$ star charity-years. The comparison is based on the rating for year $t$. Observations are first compared without controlling for size in Panel A. And then observations are matched by total assets, by total revenue, by direct support, by total contribution, and by unrestricted assets in Panel B.

Excess cash holdings is the residual from model (1) below.

Cash holdings $/$ Expense $_{\mathrm{it}}=\beta_{0}+\beta_{1}$ CVRev $_{i t}+\beta_{2}$ Ln Revenue $_{i t}+\beta_{3}$ Access to Debt $_{i t}+\beta_{4}$ Access to Debt $^{*}$ CVRev $_{i t}+\beta_{\mathrm{j}}$ State

$$
+\beta_{\mathrm{m}} \text { Year }+\varepsilon_{\mathrm{it}}
$$

where Cash Holdings is liquid assets that is the total of cash (line 45, column b), savings (line 46, column b), investments on publicly-traded securities (line 54a, column b), and investments on other securities (line 54b, column b); Expenses is total expenses (line 17); CVRev is the coefficient of variation of total revenue (line 12), measured as the ratio of the standard deviation of total revenue to the mean of total revenue over the last five years up to the year of rating; Ln Revenue is the natural logarithm of total revenue (line 12); Access to Debt is an indicator variable, equals 1 if the charity has tax-exempt bond liabilities (line 64a, column b) or mortgages and other notes payable (line 64b, column b) in the last five years up to the year of rating; Access to Debt*CVRev is the interaction term of Access to Debt and CVRev; State is the indicator variables for states; and Year is the indicator variables for year. 
Table 5. Effect of four-star rating on pay-performance sensitivity

\begin{tabular}{|c|c|c|c|c|c|}
\hline Variable & (I) & (II) & (III) & (IV) & $(\mathrm{V})$ \\
\hline Intercept & $\begin{array}{c}5.116^{* * *} \\
(15.99)\end{array}$ & $\begin{array}{l}5.095 * * * \\
(16.00)\end{array}$ & $\begin{array}{c}5.022 * * * \\
(14.21)\end{array}$ & $\begin{array}{c}4.868 * * * \\
(15.70)\end{array}$ & $\begin{array}{c}6.025 * * * \\
(12.63)\end{array}$ \\
\hline Ln Revenue & $\begin{array}{c}0.434 * * * \\
(22.69)\end{array}$ & $\begin{array}{c}0.439 * * * \\
(22.93)\end{array}$ & $\begin{array}{c}0.443 * * * \\
(20.25)\end{array}$ & $\begin{array}{c}0.458 * * * \\
(24.27)\end{array}$ & $\begin{array}{c}0.383 * * * \\
(12.41)\end{array}$ \\
\hline Ln Program Ratio & $\begin{array}{l}-0.132 \\
(-1.48)\end{array}$ & $\begin{array}{l}-0.102 \\
(-1.18)\end{array}$ & $\begin{array}{l}-0.105 \\
(-1.20)\end{array}$ & $\begin{array}{l}-0.057 \\
(-0.74)\end{array}$ & $\begin{array}{c}3.795 * * * \\
(2.66)\end{array}$ \\
\hline 4-Star & & $\begin{array}{c}-0.108 * * * \\
(-2.73)\end{array}$ & $\begin{array}{l}0.117 \\
(0.24)\end{array}$ & $\begin{array}{c}-0.523 * * * \\
(-5.88)\end{array}$ & $\begin{array}{l}-0.123 \\
(-0.11)\end{array}$ \\
\hline Ln Revenue*4-Star & & & $\begin{array}{l}-0.014 \\
(-0.45)\end{array}$ & & $\begin{array}{l}-0.023 \\
(-0.34)\end{array}$ \\
\hline $\begin{array}{l}\text { Ln Program Ratio* } \\
\text { 4-Star }\end{array}$ & & & & $\begin{array}{c}-2.881 * * * \\
(-5.11)\end{array}$ & $\begin{array}{l}11.206 \\
(1.61)\end{array}$ \\
\hline Ln Revenue* Ln Program & & & & & $-0.259 * * *$ \\
\hline $\begin{array}{l}\text { Ln Revenue* Ln Program } \\
\text { Ratio*4-Star }\end{array}$ & & & & & $\begin{array}{c}-0.898 * * \\
(-2.03)\end{array}$ \\
\hline State Dummy & Yes & Yes & Yes & Yes & Yes \\
\hline Year Dummy & Yes & Yes & Yes & Yes & Yes \\
\hline $\mathrm{N}=$ & 2293 & 2293 & 2293 & 2293 & 2293 \\
\hline $\mathrm{R}^{2}=$ & $42.82 \%$ & $43.11 \%$ & $43.12 \%$ & $45.14 \%$ & $45.27 \%$ \\
\hline$\#$ of clusters $=$ & 815 & 815 & 815 & 815 & 815 \\
\hline
\end{tabular}

This table presents the effect of the four-star rating on pay-performance sensitivity. Ln Compensation is the natural logarithm of total compensation (column A of lines 25a, 25b, and 25c); Ln Program Ratio is the natural logarithm of program expenses (line 13) as a ratio of total expenses (line17); 4-Star is an indicator variable, equals 1 if the rating is a four-star, and 0 otherwise; State is the indicator variables for states; and Year is the indicator variables for year. Under the parameter estimates are t-statistics in parentheses, calculated based on clustered standard errors. **,*** represent significance at 5 and 1 percent level, respectively (two-tailed). 
Table 6. Comparison of financial vulnerability (rating $=4$ vs. rating $=0 \sim 3$ )

Panel A: Correlations between variables used to calculate financial vulnerability and variables to calculate charity navigator ratings

\begin{tabular}{|c|c|c|c|c|c|c|c|c|c|c|c|c|c|c|}
\hline & (1) & (2) & (3) & (4) & (5) & (6) & (7) & (8) & (9) & (10) & (11) & (12) & (13) & (14) \\
\hline (1) Debt & & & & & & & -0.066 & 0.032 & 0.060 & 0.153 & -0.051 & -0.012 & -0.103 & -0.027 \\
\hline (2) Equity & & & & & & & -0.075 & 0.289 & -0.060 & 0.070 & -0.138 & -0.070 & 0.646 & -0.074 \\
\hline (3) Concentration & & & & & & & 0.003 & -0.021 & 0.008 & -0.010 & 0.023 & 0.015 & -0.023 & -0.011 \\
\hline (4) Margin & & & & & & & -0.019 & 0.043 & 0.000 & -0.209 & 0.326 & 0.028 & 0.199 & 0.140 \\
\hline (5) Admin & & & & & & & -0.276 & 0.558 & 0.036 & 0.207 & -0.147 & -0.073 & 0.109 & -0.153 \\
\hline (6) Size & & & & & & & 0.262 & 0.117 & -0.362 & -0.206 & -0.028 & -0.076 & 0.375 & 0.086 \\
\hline (7) Program Expenses & 0.001 & -0.299 & -0.009 & -0.048 & -0.618 & 0.113 & & & & & & & & \\
\hline $\begin{array}{l}\text { (8) Administration } \\
\text { Expenses }\end{array}$ & 0.058 & 0.425 & -0.270 & 0.070 & 0.904 & 0.121 & & & & & & & & \\
\hline (9) Fundraising Expenses & -0.053 & 0.177 & 0.131 & 0.042 & 0.216 & -0.233 & & & & & & & & \\
\hline (10) Fundraising Efficiency & 0.058 & 0.238 & -0.083 & -0.136 & 0.353 & -0.049 & & & & & & & & \\
\hline $\begin{array}{l}\text { (11) Primary Revenue } \\
\text { Growth }\end{array}$ & -0.016 & -0.108 & 0.129 & 0.376 & -0.174 & -0.026 & & & & & & & & \\
\hline $\begin{array}{l}\text { (12) Program Expenses } \\
\text { Growth }\end{array}$ & -0.008 & -0.045 & 0.103 & 0.073 & -0.092 & -0.042 & & & & & & & & \\
\hline (13) Working Capital Ratio & -0.291 & 0.713 & -0.321 & 0.329 & 0.283 & 0.405 & & & & & & & & \\
\hline (14) 4-Star & -0.064 & -0.052 & 0.020 & 0.175 & -0.216 & 0.086 & & & & & & & & \\
\hline
\end{tabular}

Panel B: Comparison of financial vulnerability

\begin{tabular}{|c|c|c|c|c|c|c|c|}
\hline \multirow[b]{2}{*}{ Variable } & \multicolumn{2}{|c|}{ Rating $=4$} & \multicolumn{2}{|c|}{ Rating $=0 \sim 3$} & \multirow[b]{2}{*}{ Difference } & \multirow[b]{2}{*}{$\mathrm{t}$} & \multirow[b]{2}{*}{$\mathrm{p}$} \\
\hline & Mean & $\begin{array}{l}\text { Std. } \\
\text { Dev. }\end{array}$ & Mean & Std. Dev. & & & \\
\hline FVI_1 & 0.088 & 0.087 & 0.091 & 0.086 & -0.003 & -0.81 & 0.42 \\
\hline$F V I \_2$ & 0.158 & 0.109 & 0.177 & 0.120 & -0.019 & -3.69 & 0.00 \\
\hline$L F \bar{V}_{-} 1$ & 0.452 & 0.498 & 0.446 & 0.497 & 0.006 & 0.27 & 0.79 \\
\hline$L F V_{-} 2$ & 0.227 & 0.419 & 0.192 & 0.394 & 0.035 & 1.85 & 0.07 \\
\hline
\end{tabular}

This table examines the correlations between variables used to compute the financial vulnerability index and variables used to calculate Charity Navigator ratings. It also compares the year $t+1$ financial vulnerability of four-star charities and lower rated charities. Variables used to compute the financial vulnerability index are obtained from Form 990s. Debt is total liabilities (line 66b) scaled by total assets (line 59b). Equity is total equity (line 59b - line 66b) divided by total revenue (line 12). Concentration is the revenue concentration ratio, which is the total of the squares of each revenue source such as contributions to donor advised funds (line 1a), direct public support (line 1b), indirect public support (line 1c) and so on as a percentage of the total revenue (line 12). Admin is the administrative expense (line 14) scaled by total revenue (line 12). Margin is the difference between total revenue (line 12) and total expense (line 17) and then scaled by total revenue. Size is the natural logarithm of total assets (line 59b).

Variables used to calculate Charity Navigator ratings are obtained directly from Charity Navigator. Program Expenses is program expenses divided by its total functional expenses. Administration Expenses is administrative expenses divided by its total functional expenses. Fundraising Expenses is fundraising expenses divided by total expenses. Fundraising Efficiency is fundraising expenses divided by total contributions. Primary Revenue Growth is computed as $\left[\left(\mathrm{Y}_{\mathrm{n}} / \mathrm{Y}_{0}\right)^{(1 / \mathrm{n})}\right]-1$, where $\mathrm{Y}_{0}$ is the revenue measured in the first year of the interval analyzed, $Y_{n}$ is the revenue measured at the end of the interval analyzed, and $n$ is the length of the interval in years varying from 2 to 4 years. Program Expense Growth is computed as $\left[\left(\mathrm{Y}_{\mathrm{n}} / \mathrm{Y}_{0}\right)^{(1 / \mathrm{n})}\right]-1$, where $\mathrm{Y}_{0}$ is the program expense measured in the first year of the interval analyzed, $Y_{n}$ is the program expense measured at the end of the interval analyzed, and $n$ is the length of the interval in years varying from 2 to 4 years. Working Capital Ratio is working capital, including cash and cash equivalents, savings, receivables, investments in securities, accounts and grants payable, and accrued expenses, divided by total expenses.

The financial vulnerability indexes: $F V I \_1$ is calculated following Greenlee and Trussel (2000):

$$
F V I \_1=1 /\left(1+e^{-\mathrm{z}}\right)
$$

where $Z=-3.0610+0.1153 *$ Equity $+1.2528 *$ Concentration $-2.2639 *$ Admin $-3.4289 *$ Margin. FVI_2 is calculated using equation (4) above (Trussel et al. 2002), but $\mathrm{Z}=0.7754+0.9272 *$ Debt $+0.1496 *$ Concentration $+0.1206 *$ Admin $-2.8419 *$ Margin $-0.1665 *$ Size . $L F V \_1$ equals 1 if $F V I \_1$ is less than 0.07 , and 0 otherwise. $L F V \_2$ equals 1 if $F V I \_2$ is less than 0.10 , and 0 otherwise.

In Panel A, correlations significant at 0.01 level are in bold, and those significant at 0.05 level are in italic. The column numbers on the top of the correlation table corresponds to the variable numbers on the left. p-values in both panels are two-tailed. 